\title{
Detect and Effects of Silicon Content in Chemical Composition of Steel Material After the Hot Dip Galvanized Coating
}

\author{
Ömer Muharrem C1lız ${ }^{1 *}$, Mustafa Gökhan Güler², Yusuf Talha Dönmez ${ }^{3}$ \\ 1* Link Yapı San. ve Tic. A.Ş., Tasarım Merkezi Departmanı, Kocaeli, Turkey, (ORCID: 0000-0002-4804-2352), omerciliz@gmail.com \\ ${ }^{2}$ Link Yapı San. ve Tic. A.Ş., Tasarım Merkezi Departmanı, Kocaeli, Turkey, (ORCID: 0000-0003-4857-3791), mgokhanguler@ gmail.com \\ ${ }^{3}$ Link Yapı San. ve Tic. A.Ş., Tasarım Merkezi Departmanı, Kocaeli, Turkey, (ORCID: 0000-0003-4125-9644), y.talhadonmez@ gmail.com
}

(International Conference on Design, Research and Development (RDCONF) 2021 - 15-18 December 2021)

(DOI: 10.31590/ejosat.1041541)

ATIF/REFERENCE: C1lız, Ö.M., Güler, M.G., Dönmez, Y.T., (2021). Detect and Effects of Silicon Content in Chemical Composition of Steel Material After the Hot Dip Galvanized Coating Process. European Journal of Science and Technology, (32), 306-311.

\begin{abstract}
We are looking for permanent solutions to the problems based on global warming, which is one of the main agenda items of the world and our country; In the light of critical considerations such as sustainability, efficient use of resources, and prevention of waste; protection of steel from corrosion has become a obligation beyond necessity in order to protect and make sustainable the values produced by the increased use of steel. In this article, which includes the details of our study on the visual variability that occurs after the hot dip galvanizing process, which is widely used to protect the raw material resources of our world and the energy spent to bring these resources to the economy, and the determination of the silicon content after coating, The processes that it is involved in from corrosion to its separation from the structure and the results it causes are discussed.
\end{abstract}

Keywords: Silicon, Steel, Galvanic, Hot-Dip Galvanize, Post-Coating, Destructive Failure Analize, Coating.

\section{Çelik Malzemelerdeki Silisyum Oranın Sıcak Daldırma Galvaniz Kaplama Sonrasında Tespiti ve Kaplama Üzerindeki Etkileri}

$\ddot{O} \mathbf{z}$

Dünya ve ülkemizin başlıca gündem maddelerinden olan küresel ısınmaya dayalı sorunlara kalıcı çözümler aradığımız bu zamanlarda; sürdürülebilirlik, kaynakların verimli kullanımı, israfın önlenmesi gibi kritik değerlendirmeler ışı̆̆ında artan çelik kullanımı ile üretilen değerlerin korunması, sürdürülebilir kılınması için çeliğin korozyondan korunması ihtiyacın ötesinde bir zaruret olmuştur. Dünyamızın hammadde kaynakları ile bu kaynakların ekonomiye kazandırılmasında harcanan enerjinin korunması için yaygın kullanılan sıcak daldırma galvaniz prosesi sonrasında ortaya çıkan görsel değişkenlikler ile bu değişkenliğin nedeni olan silisyum içeriğinin kaplama sonrası tespitine dair çalışmamızın detaylarının yer aldığı bu makalede, demir cevherinin çeliğe dönüşümünde dâhil olan silikonun korozyon ile yapıdan ayrılmasına kadar dâhil olduğu süreçler ve neden olduğu sonuçlar ele alınmıştır.

Anahtar Kelimeler: Silisyum, Çelik, Galvaniz, Sıcak Daldırma Galvaniz, Kaplama Sonrası, Hasarlı Kusur Analizi, Kaplama.

\footnotetext{
* Corresponding Author: omerciliz@gmail.com
} 


\section{Introduction}

One of the main criteria to consider when designing a new or improving an existing one is material selection. Material selection is made by taking into account the needs of the design such as load, cost, availability, visuality, compliance with environmental conditions, and life. In cases where it is not possible to meet all the needs, additional improvements should be made for the inadequacies of the materials used.

In designs where metal materials are used, the primary selection criteria are mechanical performance and costs, as a result of which it is inevitable to resort to coating types for secondary requirements such as life and sustainability as well as cosmetic requirements.

Another point to be considered while choosing among the developing and widespread coating types is the applicability in addition to the previous ones. The guidelines for common coating types related to applicability are the relevant standards, for which selection of these standards should take into account their compliance with the requirements as well as the provisions of authorities such as public bodies. For example, although different applications are technically possible, the application of TS EN ISO 1461 standard for Hot Dip Galvanizing applications to be made in Turkey is a necessity as per the second article of the relevant communique.

"The TS EN ISO 1461 "Hot-Dip Galvanized Coatings on Materials Made of Iron and Steel - Properties and Test Methods" standard, prepared by the Turkish Standards Institute, is mandatory during the manufacturing and sales phases." (TS EN ISO 1461, 2011).

Although there are expressions regarding appearance, such as " The primary purpose of the galvanized coating is to protect the underlying iron or steel material from corrosion. Aesthetic or decorative considerations should be the secondary goal.'or " The occurrence of dark or gray areas (such as cellular image or dark gray areas) or surface unevenness should not be considered a reason for rejection.' in article 6.1 of the TS EN ISO 1461 standard, efforts to respond to increasing customer expectations in recent years, even by offering more than these expectations, have led to the inclusion of visuality among the product acceptance criteria (TS EN ISO 1461, 2011).

In this study, the visual results that occur depending on the ratio of silica $(\mathrm{Si})$, which is one of the steel contents coated with the hot-dip galvanized coating method, in the material chemical content are examined. These evaluations are based on the reverse engineering approach, the chemical contents of the product with two different coating visuals were determined by the spectral analysis method and the evaluations made were technically verified.

\section{Hot Dip Galvanized Coating}

The scientific history of hot-dip galvanizing begins with the article presented to the French Royal Academy by French chemist Paul Jacques Malouin in 1742, explaining how to obtain a zinc coating by dipping iron into molten zinc (GA, 2021). The main purpose of this coating, which is widely used today, is to protect steels from corrosion. To fully understand this protection, it is necessary to define the concepts of steel, corrosion and coating.

\subsection{Steel Alloy}

Steel is an alloy of the element iron combined with a limited amount of carbon and some additional elements as needed. Iron ores are found in nature in the form of Magnetite $\left(\mathrm{Fe}_{3} \mathrm{O}_{4}\right)$, Hematite $\left(\mathrm{Fe}_{2} \mathrm{O}_{3}\right)$, Limonite $\left(2 \mathrm{Fe}_{2} \mathrm{O}_{3} \cdot 2 \mathrm{H}_{2} \mathrm{O}\right)$, Goethite $\left(\mathrm{Fe}_{2} \mathrm{O}_{3} \cdot \mathrm{H}_{2} \mathrm{O}\right)$, Siderite $\left(\mathrm{FeCO}_{3}\right)$ and Pyrite $\left(\mathrm{FeS}_{2}\right)$ minerals (MTA, 2021).

Deoxygenated raw iron is obtained from iron oxide ores passed through blast furnaces. Liquid steel coming out of the blast furnace contains around $3.5 \%$ to $4.5 \%$ carbon, along with $0.7-3.5 \%$ silicon and various amounts of auxiliary elements such as manganese, phosphorus and sulfur. These additives are burned by giving oxygen to the liquid steel in various ways. (Mohsunlu, 2021).

Oxygen first reacts with the iron, which is the most abundant, $\left(2 \mathrm{Fe}+\mathrm{O}_{2} \rightarrow 2 \mathrm{FeO}\right)$ to form iron oxide $(\mathrm{FeO})$. The $\mathrm{FeO}$ formed dissolves in the liquid raw iron and reacts with the side elements. The reactions that occur are (Mohsunlu, 2021);

$$
\begin{array}{lcc}
\text { - } & 2 \mathrm{FeO}+\mathrm{Si} \rightarrow & \rightarrow \mathrm{Fe}+\mathrm{SiO}_{2} \\
\text { - } & \mathrm{FeO}+\mathrm{Mn} \rightarrow \mathrm{Fe}+\mathrm{MnO} \\
\text { - } & \mathrm{FeO}+\mathrm{C} \rightarrow \mathrm{Fe}+\mathrm{CO} \\
\text { - } & 2 \mathrm{FeO}+\mathrm{S} \rightarrow \mathrm{Fe}+\mathrm{SO}_{2} \\
\text { - } & 5 \mathrm{FeO}+2 \mathrm{P} \rightarrow 5 \mathrm{Fe}+\mathrm{P}_{2} \mathrm{O}_{5}
\end{array}
$$

In the above process, called oxidation reactions, the amount of carbon was reduced, and our alloy, which we can now call steel, contains a high amount of oxygen. During steel production, the oxygen in the structure prevents the homogeneity of the chemical composition of the steel. This process of reducing the oxygen level is called deoxidation and $\mathrm{Si}, \mathrm{Al}$ and Mn elements are used for this (Tetik, 2015).

According to the type of deoxidation, the steels are divided into three as rimmed, semi-killed and killed. Killed steels usually contain $0.15 \%$ to $0.35 \% \mathrm{Si}$, while semi-killed steels contain less than $0.10 \%$ (usually $0.03 \% \mathrm{Si}$ ) (TWI-Global, 2021).

Silicon: It has an oxide cleaner feature on steel. It has the effect of increasing the strength and yield limit of steel. It provides hardening up to the core (Burhan, 1985).

The amount of silicon varies depending on whether the steel sheet is killed or not. While it is less than $0.10 \%$ in rimmed steels, its ratio in the composition can increase up to $0.40 \%$ when added for calming purposes. Silicon increases the tensile strength and therefore reduces the formability. At the same time, it is present in the structure as silicate residues, increasing the possibility of cracking in bending operations (Değirmenci, 2006).

\subsection{Corrosion}

Corrosion is the degradation of a material by its environment. In the case of metals, corrosion is an electrochemical reaction between a metal and its environment (American Society of Plumbing Engineers, 2013). The tendency of metals to return to their natural state can be considered as the main cause of corrosion, noble metals such as gold, silver and platinum, which are not oxidized in nature, are all subject to different types of corrosion depending on environmental conditions. (Korozyon Derneği, 2021). 
It is the degradation of metals and alloys as a result of chemical and electrochemical reactions with their environment. Chemical corrosion is the oxidation of metals and alloys in gaseous environments (dry corrosion). The degradation of metals and alloys in aqueous environments is called electrochemical or wet corrosion. (Aygün, 2003).

Corrosion is an electrochemical process that requires the flow of electrons and ions. Metal loss (corrosion) occurs at the anode. There is no metal loss at the cathode. Electrochemical corrosion requires electron transfer at the metal/electrolyte interface. Corrosion occurs in a corrosion cell consisting of 4 parts (Anode + Cathode + Electrolyte + Metallic Bond). Electrons formed by the production of metallic ions at the anode pass over the electrical path and pass to the cathodic surface immersed in the electrolyte. They re-establish the electrical balance by reacting with the positively charged ions in the electrolyte. (İşdaş, 2010).

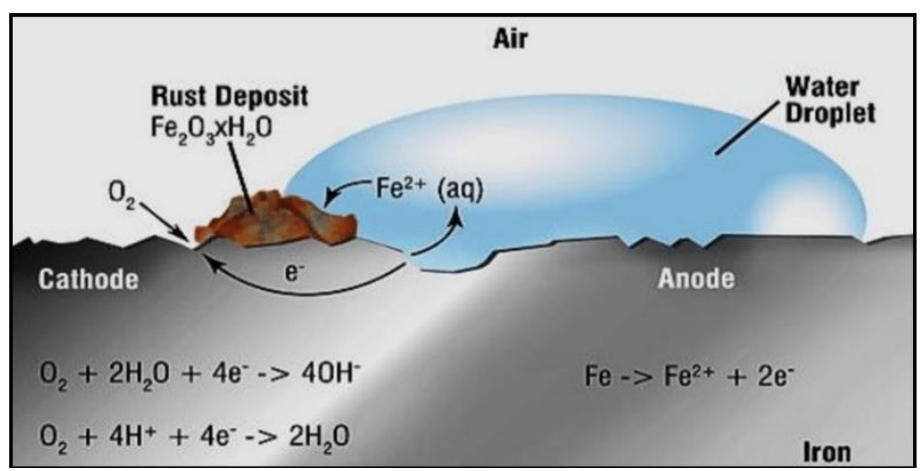

Figure 1. Chemical Equations of Corrosion (Aljamali, 2019)

Iron-2 $\left(\mathrm{Fe}(\mathrm{OH})_{2}\right)$ hydroxide formed as a result of corrosion is re-oxidized into iron-3 hydroxide $\left(\mathrm{Fe}(\mathrm{OH})_{3}\right)$ (rust) if there is sufficient oxygen in the environment. (Aljamali, 2019).

$$
2 \mathrm{Fe}(\mathrm{OH})_{2}+1 / 2 \mathrm{O}_{2}+\mathrm{H}_{2} \mathrm{O} \rightarrow 2 \mathrm{Fe}(\mathrm{OH})_{3}
$$

The costs imposed by corrosion on economies reach levels that are proportional to the national incomes of nations. On the other hand, losses that cannot be compensated reveal that taking measures to prevent them is a obligation rather than a necessity. Some of the accidents caused by corrosion can be seen below:

- In the accident that took place in India in 1984, at least 15,000 people died and 150,000 - 600,000 people were disabled as a result of the explosion of a 40-ton tank full of methyl isocyanate (MIC) due to the corrosion effect (Wikipedia, 2021).

- In 1992, in Mexico, more than 200 people died and nearly a thousand buildings were damaged as a result of a sewage explosion caused by corrosion. The explosion occurred when the gasoline leak, which started from a single hole caused by corrosion between the steel gasoline pipe and the zinc-coated water pipe, mixed into the sewer (History, 1992).

- On April 28, 1988, a BOEING 737 aircraft belonging to Aloha Airlines entered world flight history. The plane flying to Hawaii suddenly experienced a huge explosion. Due to corrosion, the aircraft's fuel panel shattered at 24000 feet (Aviation Safety Network, 1988).

\subsection{Corrosion Protection}

The primary approach in protecting steels from corrosion should be to minimize the risks at the design stage. We can consider this approach in the topics of material selection, control of ambient conditions and design features (Tansel, 1995).

However, it is obvious that it is not possible to completely control these conditions. Therefore, in these conditions where regulatory measures are insufficient, preventive measures should be taken. Corrosion protection methods are mainly based on two principles, which are cathodic protection and coating.

Cathodic protection requires polarization of corroding metals as cathodes. This can be achieved by pairing the metal to be protected with a more active metal (galvanic anode or sacrificial anode) or by applying an external current. (Tuna, 2013).

When it comes to coating, one of the first methods that comes to mind is paint systems. The working principle of this type of protection is completely based on preventing chemical reactions that will occur by isolating the material from external environmental conditions such as the atmosphere.

Hot Dip Galvanizing Method, which is one of the metal coating methods, is widely used in the iron and steel industry thanks to its good protective coating and cathodic protection.

The hot-dip galvanizing process is carried out by immersing the steels, whose surfaces are cleaned, into pools, which are defined as galvanized baths with a zinc content of more than $98.5 \%$, which are molten at an average of 450 degrees and after waiting for a certain (reaction) time, they are removed from the pool as coated at a certain speed.

During galvanizing, liquid zinc reacts with the iron or steel surface to form various zinc/iron layers (AGA, 2021).

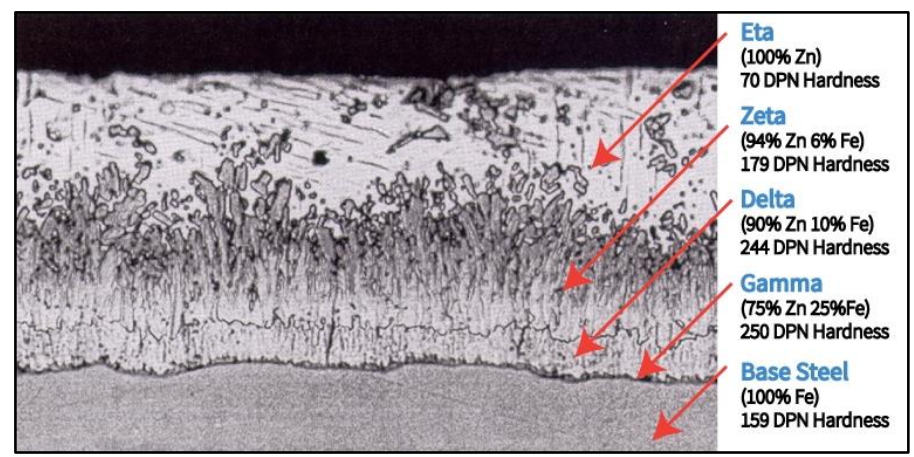

Figure 1. Photomicrograph of hot-dip galvanized (AGA, 2021)

On the other hand, a good galvanized coating is evaluated with the amount of zinc it can sacrifice, namely its thickness; Scientist R. Sandelin was the first to reveal in the early 1940s that one of the main factors affecting this thickness was the silicon ( $\mathrm{Si}$ ) content in steel chemistry (Yaamonde \& González, 1991). 


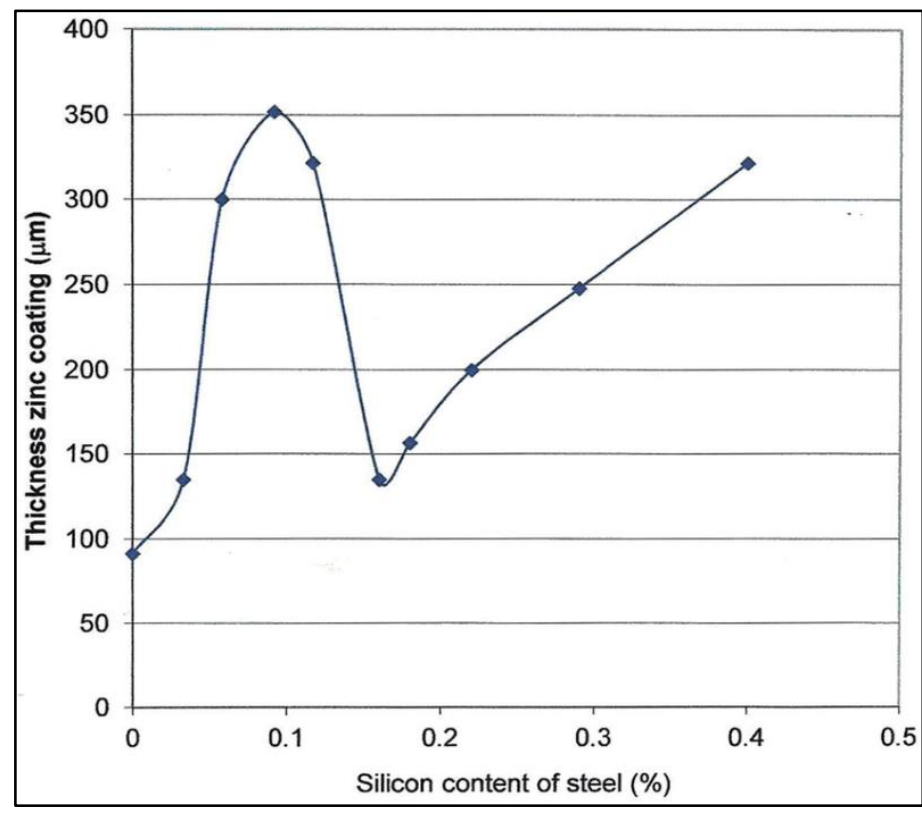

Figure 2. Sandelin Curve (Chatterjee, 2014)

The silicon content will result in galvanized coatings that are either thicker or thinner according to the underlying steel thickness. Thicker coatings result from the increased reactivity of the steel with molten zinc and the rapid growth of zinc-iron alloy layers on the steel surface. When the silicone content is less than $0.04 \%$, the appearance will typically be glossy and aesthetically appealing. When the silicone content is less than $0.01 \%$, the coating will also be aesthetically appealing, although it may be of lesser thickness than required by the standard. If the silicon content is between $0.04 \%$ and $0.14 \%$, extremely thick gray coatings may develop, which can lead to instability in coating adhesion and cohesion (GGA, 2021).

Table 1. Sandelin Curve Based View Table (ZINQ, 2021)

\begin{tabular}{|c|c|c|c|c|}
\hline Class & $\begin{array}{lcl}\mathbf{S i} \quad \text { \& } & \text { P } \\
\text { Relationship } & \end{array}$ & $\begin{array}{l}\text { Visual } \\
\text { Aspect }\end{array}$ & $\begin{array}{l}\text { Impact } \\
\text { Strength }\end{array}$ & $\begin{array}{l}\text { Mass of } \\
\text { coating }\end{array}$ \\
\hline$X$ & $\begin{array}{l}\mathrm{Si} \leq 0.01 \% \text { and } \\
\mathrm{Al}>0.035 \%\end{array}$ & \multirow{2}{*}{$\begin{array}{l}\text { Excellent, } \\
\text { typically } \\
\text { shiny }\end{array}$} & \multirow[t]{2}{*}{ Perfect } & $\begin{array}{l}\text { Minimum } \\
\text { but can } \\
\text { sometimes } \\
\text { be under } \\
\text { standard }\end{array}$ \\
\hline A & $\begin{array}{l}\mathrm{Si} \leq 0.04 \% \text { and } \\
\mathrm{P} \leq 0.02 \% \text { and } \\
\mathrm{Si}+2.5 \mathrm{P} \leq 0.09 \%\end{array}$ & & & Standard \\
\hline B & $0.14 \%<\mathrm{Si} \leq 0.25 \%$ & $\begin{array}{l}\text { Good, } \\
\text { mottled or } \\
\text { dull acc. } \\
\text { to steel } \\
\text { thickness }\end{array}$ & Good & $\begin{array}{l}\text { Always } \\
\text { heavier } \\
\text { than } \\
\text { normal }\end{array}$ \\
\hline $\mathrm{C}$ & $0.04 \%<\mathrm{Si} \leq 0.14 \%$ & \multirow[b]{2}{*}{$\begin{array}{l}\text { Can be } \\
\text { dark and } \\
\text { coarse }\end{array}$} & \multirow[b]{2}{*}{ Poor } & $\begin{array}{l}\text { Extra } \\
\text { heavy }\end{array}$ \\
\hline $\mathrm{D}$ & $\mathrm{Si}>0.25 \%$ & & & $\begin{array}{l}\text { High } \\
\text { Coating } \\
\text { acc. to the } \\
\mathrm{Si} \text { content } \\
\text { increases }\end{array}$ \\
\hline
\end{tabular}

When the silicone content exceeds about $0.25 \%$, the coating usually tends to a gray color and is always thicker than the Standard and this means it is more susceptible to shipping damage at the edges. However, in most cases, a silicon content above $0.25 \%$ would be acceptable due to increased durability benefits to the user. Higher silicon content is desired in some applications where very long term durability is desired, such as bridges (GGA, 2021).

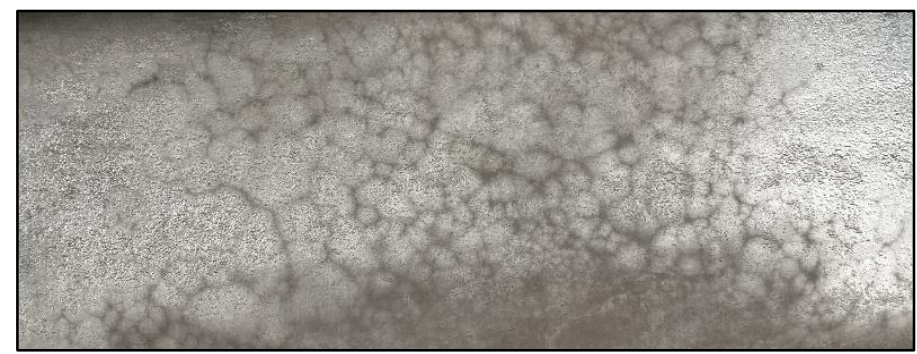

Figure 3. Mottled Appearance of a Newly Galvanized Metal

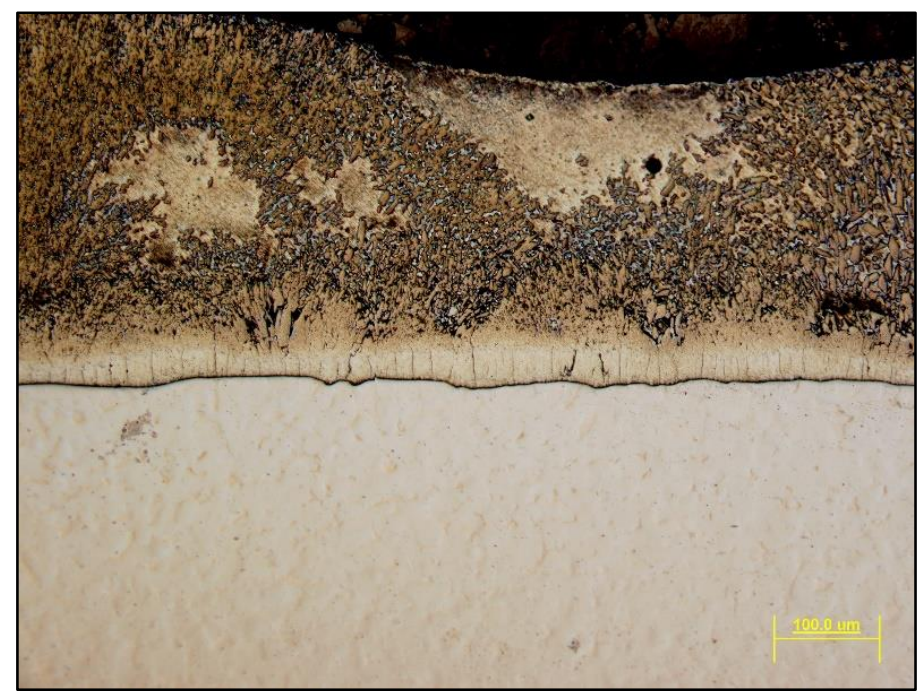

Figure 4. Micrograph of a Partially Matt, Partially Glossy Galvanized (GGA, 2021)

On the other hand, reactive coatings cause problems in the appearance and mechanical properties of galvanized coatings, and also lead to the formation of excessive coatings on the steel, which increases the cost of the galvanizing process. To avoid this problem, the silicon content of the steels to be galvanized is kept below 0.03\% (Küçükkaragöz \& Elkoca, 2016).

\section{Detection of \%Si After Coating}

\subsection{Nonconformity Detection}

The visual variability resulting from the same bath dive, in other words, the common coating process, was demonstrated in visual control.

In the coating thickness measurements made with a nitrometer device to support this examination; While the coating thickness for Sample-1 was in the order of $100 \mu \mathrm{m}$, it was determined that the coating thickness of Sample-2 reached the order of $600 \mu \mathrm{m}$. 


\subsection{Chemical Composition Analysis After Coating}

Although the reason for the negative results is theoretically estimated as \% Si content under the guidance of the Sandelin Curve, non-destructive testing about the chemical composition cannot be performed due to the zinc coating formed. In order to verify the theoretically determined situation in practice, first of all, the coating layers on the samples were scraped by mechanical grinding.

Then, measurements were made with an optical emission spectrometer device on the exposed steel surface that did not react with zinc.
All known elements emit radiation with different properties when exposed to electric current. When these radiations are analyzed and examined with a spectrometer device, it is seen that each element has its own specific spectrum line. According to these properties, the elements and their amounts in metallic materials are determined. The chemical contents reached as a result of the measurements are shown below. Accordingly, the presence of relatively very high $\% \mathrm{Si}$ content in the chemical content of the dark colored sample with an

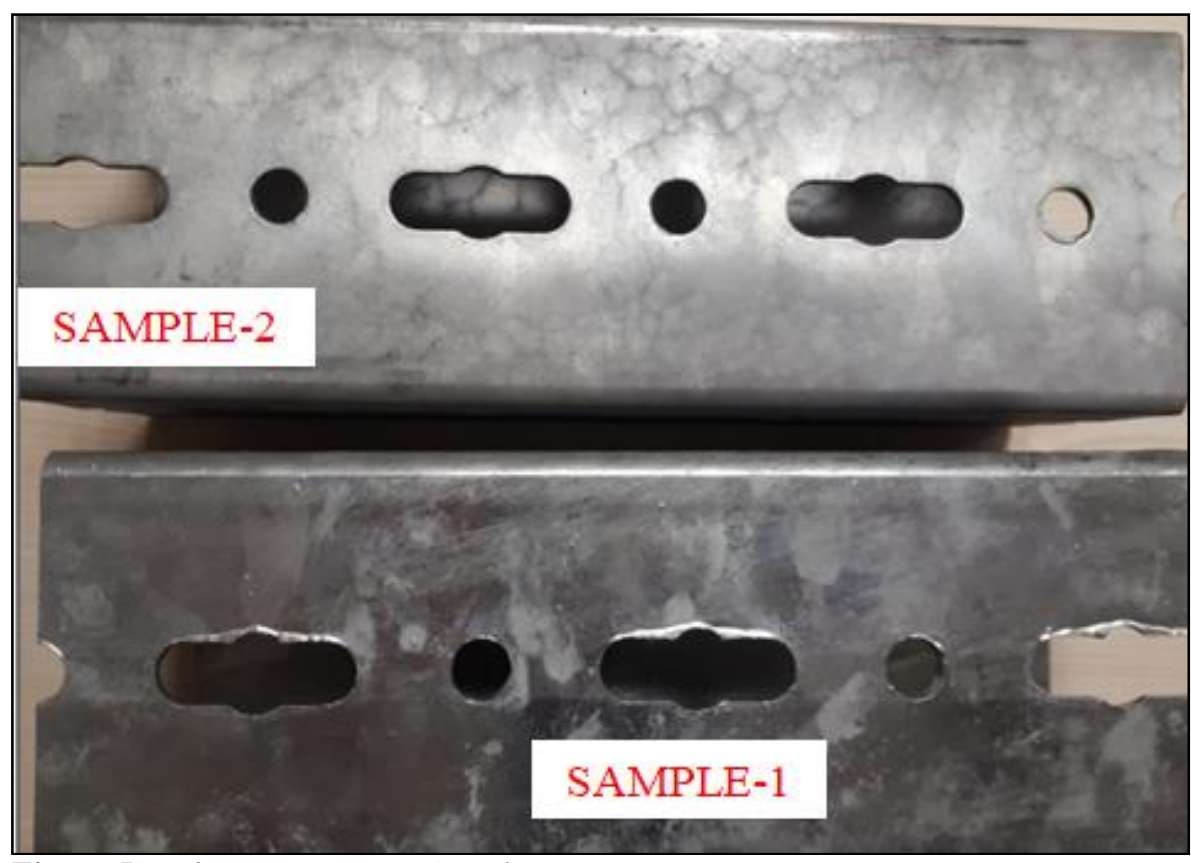

Figure 5. Before Testing Test Samples Views

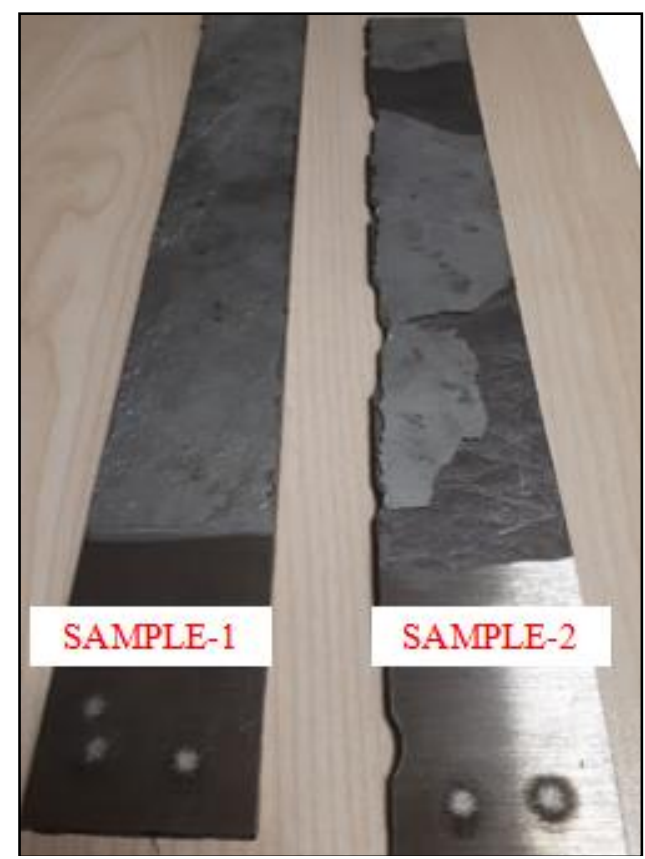

Figure 7. Sample Views After Testing

Table 2. Spectrometer Analysis Results

\begin{tabular}{|l|l|l|l|l|l|l|l|l|l|l|l|}
\hline Sample & Test & $\% \mathrm{Fe}$ & $\% \mathrm{C}$ & $\% \mathrm{Si}$ & $\% \mathrm{Mn}$ & $\% \mathrm{P}$ & $\% \mathrm{~S}$ & $\% \mathrm{Cr}$ & $\% \mathrm{Mo}$ & $\% \mathrm{Ni}$ & $\% \mathrm{Al}$ \\
\hline \multirow{4}{*}{ N.1 - 4mm } & I. Measurement & 98,7 & 0,182 & 0,0123 & 0,911 & 0,0203 & 0,0050 & 0,0286 & $<0,005$ & 0,0288 & 0,0258 \\
\cline { 2 - 10 } & II. Measurement & 98,6 & 0,185 & 0,0141 & 0,934 & 0,0219 & 0,0055 & 0,0305 & $<0,005$ & 0,0300 & 0,0267 \\
\cline { 2 - 11 } & Average & 98,6 & 0,184 & 0,0132 & 0,922 & 0,0211 & 0,0053 & 0,0296 & $<0,005$ & 0,0294 & 0,0262 \\
\hline \multirow{3}{*}{ N.2-3mm } & I. Measurement & 99,3 & 0,053 & $\mathbf{0 , 0 6 2 6}$ & 0,236 & 0,0196 & 0,0149 & 0,0245 & $<0,005$ & 0,0416 & 0,0521 \\
\cline { 2 - 11 } & II. Measurement & 99,3 & 0,056 & $\mathbf{0 , 0 6 4 0}$ & 0,242 & 0,0203 & 0,0157 & 0,0246 & $<0,005$ & 0,0448 & 0,0529 \\
\cline { 2 - 10 } & Average & 99,3 & 0,055 & $\mathbf{0 , 0 6 3 3}$ & 0,239 & 0,0199 & 0,0153 & 0,0245 & $<0,005$ & 0,0432 & 0,0525 \\
\hline
\end{tabular}

\begin{tabular}{|c|c|c|c|c|c|c|c|c|c|c|c|}
\hline Sample & $\% \mathrm{Co}$ & $\% \mathrm{Cu}$ & $\mathrm{Nb}$ & $\mathrm{Ti}$ & V & W & $\mathrm{Pb}$ & $\mathrm{Sn}$ & B & $\mathrm{Zr}$ & As \\
\hline \multirow{3}{*}{$\begin{array}{l}N .1 \\
\text { continue of } \\
4 m m\end{array}$} & $<0,005$ & 0,0205 & $<0,002$ & 0,0025 & 0,0048 & $<0,005$ & 0,0101 & 0,0020 & $<0,001$ & 0,0032 & 0,0170 \\
\hline & $<0,005$ & 0,0197 & $<0,002$ & 0,0028 & 0,0050 & $<0,005$ & 0,0092 & 0,0023 & $<0,001$ & 0,0044 & 0,0244 \\
\hline & $<0,005$ & 0,0201 & $<0,002$ & 0,0026 & 0,0049 & $<0,005$ & 0,0096 & 0,0021 & $<0,001$ & 0,0038 & 0,0207 \\
\hline \multirow{3}{*}{$\begin{array}{l}N .2 \\
\text { continue of } \\
3 \mathrm{~mm}\end{array}$} & $<0,005$ & 0,0736 & $<0,002$ & 0,0023 & 0,0040 & $<0,005$ & 0,0079 & 0,0033 & $<0,001$ & 0,0059 & 0,0251 \\
\hline & $<0,005$ & 0,0733 & $<0,002$ & 0,0017 & 0,0040 & $<0,005$ & 0,0085 & 0,0037 & $<0,001$ & 0,0048 & 0,0292 \\
\hline & $<0,005$ & 0,0735 & $<0,002$ & 0,0020 & 0,0040 & $<0,005$ & 0,0082 & 0,0035 & $<0,001$ & 0,0053 & 0,0271 \\
\hline
\end{tabular}




\section{Conclusions and Recommendations}

Unlike many studies seen in this study, it has been revealed that the undesirable situation is based on $\% \mathrm{Si}$ content in the analysis of the damaged product regarding the cause of visual problems after hot-dip galvanized coating. Therefore, a reliable analysis methodology that can be used in case-detection and cause-effect studies has been put forward.

\section{Acknowledge}

I would like to thank all LINK Yapı employees who contributed to this work and the Republic of Turkey Ministry of Industry and Technology for their support to LINK Yapı Design Center activities.

\section{References}

AGA. (2021, 10 27). The HDG Coating. Retrieved from American Galvanizers Association: https://galvanizeit.org/hot-dip-galvanizing/what-isgalvanizing/the-hdg-coating

Aljamali, N. M. (2019, 07 04). Review on Corrosion and Rust Inhibition of Machines in Chemical Engineering Field. JournalsPub, 15-24.

American Society of Plumbing Engineers. (2013). CEU 256 Corrosion. In Engineers, American Society of Plumbing (p. 2). American Society of Plumbing Engineers.

Aviation Safety Network. (1988, Nisan 23). Retrieved from Aviation Safety Network: https://aviationsafety.net/database/record.php?id=19880428-0

Aygün, H. (2003). Korozyon ve Jeotermal Uygulamalar. Jeotermal Semineri (p. 423). Ankara: Makine Mühendisleri Odas1.

Burhan, O. (1985). Alaşım elementlerinin Çeliklerin Kaynak Kabiliyetine Etkisi. In Karbonlu ve Alaşımlı Çeliklerin Kaynağı. Oerlikon Yayınları.

Chatterjee, B. (2014). Hot Dip Galvanizing. Jahrbuch Oberflächentechnik Band 70, 11.

Değirmenci, H. (2006). Çelik Sacların Mekanik Özelliklerinde Ortaya Çıkan Değişimler Ve Nedenleri İle Bunların Şekillendirme Prosesi Üzerindeki Etkileri (Yüksek Lisans Tezi). İstanbul: Yıldız Teknik Üniversitesi.

GA. (2021). History of galvanizing. Retrieved from İngiltere ve İrlanda Galvanizciler Derneği: https://www.galvanizing.org.uk/hot-dip-galvanizing/historyof-galvanizing/

GGA. (2021, 10 28). Metallurgy of galvanizing. Retrieved from Galvanizers Association of Australia: https://designmanual.gaa.com.au/index.php/process/metallur gy-of-galvanizing/

History. (1992, Nisan 22). Sewers explode in Guadalajara, Mexico, Killing Hundreds. Retrieved from https://www.history.com/this-day-in-history/sewers-explodein-guadalajara

İşdaş, O. (2010). Elektrokimyasal Korozyon İlkeleri. TMMOB Metalurji Mühendisleri Odası, 45.

Korozyon Derneği. (2021). Korozyon ve Önemi. Retrieved from Korozyon Derneği: http://www.korozyondernegi.org.tr/tr/

Küçükkaragöz, C., \& Elkoca, O. (2016, Eylül). Galvanizing of Silicon Containing Steels: Effect of Mechanical Surface Treatments on Sandelin Phenomenon. Hittite Journal of Science and Engineering, 81-85.
Mohsunlu, S. (2021). Çelik Üreten Bir Endüstri Tesisinde Enerji Maliyetinin Düşürülmesi Çalışması (Yüksek Lisans Tezi). Karabük: Karabük Üniversitesi.

MTA. (2021). Demir. Retrieved from Maden Tetkik ve Arama Genel Müdürlüğü: https://www.mta.gov.tr/v3.0/metalikmadenler/demir

T.C. Sanayi ve Teknoloji Bakanlığı. (2011, 12 31). Demir ve Çelikten Imal Edilmiş Malzemeler Üzerine Sicak Daldırmayla Yapılan Galvaniz Kaplamalar İle İlgili Tebliğ (TS EN ISO 1461) (2011, 31Arallk). Retrieved from Resmi Gazete (Sayı: 28159) (TEBLIĞ NO:MSG-MS-2011/16): https://www.resmigazete.gov.tr/eskiler/2011/12/2011123112.htm

Tansel, O. (1995). Gemilerin Korozif Etkilerden Korunma Yöntemlerinin Araştırılması (Yüksek Lisans Tezi). İstanbul: İstanbul Üniversitesi.

Tetik, Y. (2015). Alüminyum Tüketimini Azaltmak Iç̧in Kok ile Ön Deoksidasyon İşlemi ve Prensibi (Yüksek Lisans Tezi). İstanbul: İstanbul Teknik Üniversitesi.

TS EN ISO 1461. (2011, Temmuz). Demir ve Çelikten İmal Edilmiş Malzemeler Üzerine Sıcak Daldırmayla Yapılan Galvaniz Kaplamalar - Özellikler ve Deney Metotları. Ankara: TSE.

Tuna, N. (2013). Çinko ve Nikel Kaplanmış Düşük Karbonlu Çelik Plaka ve Vidaların Korozyon Davranışının İncelenmesi (Yüksek Lisans Tezi). İstanbul: İstanbul Teknik Üniversitesi.

TWI-Global. (2021). CHARACTERISTICS OF STEELS FROM DIFFERENT DEOXIDATION METHODS. Retrieved from https://www.twi-global.com/technical-knowledge/faqs/faqwhat-are-the-distinguishing-characteristics-of-steels-madeusing-different-deoxidation-practices

Wikipedia. (2021). Bhopal Disaster. Retrieved from Wikipedia: https://en.wikipedia.org/wiki/Bhopal_disaster

Yaamonde, A., \& González, J. (1991). The Sandelin effect and continuously cast steels. International Journey of Materials and Product Technology, 175-216.

ZINQ. (2021, Kasım 02). Retrieved from www.zinq.fr: https://www.zinq.fr/ 